\title{
WestVirginiaUniversity
}

THE RESEARCH REPOSITORY @ WVU

West Virginia Agricultural and Forestry Experiment Davis College of Agriculture, Natural Resources

Station Bulletins

And Design

$1-1-1966$

\section{Crisscross breeding of poultry}

H. M. Hyre

M. R. McClung

Follow this and additional works at: https://researchrepository.wvu.edu/ wv_agricultural_and_forestry_experiment_station_bulletins

\section{Digital Commons Citation}

Hyre, H. M. and McClung, M. R., "Crisscross breeding of poultry" (1966). West Virginia Agricultural and Forestry Experiment Station Bulletins. 526T.

https://researchrepository.wvu.edu/wv_agricultural_and_forestry_experiment_station_bulletins/666

This Bulletin is brought to you for free and open access by the Davis College of Agriculture, Natural Resources And Design at The Research Repository @ WVU. It has been accepted for inclusion in West Virginia Agricultural and Forestry Experiment Station Bulletins by an authorized administrator of

The Research Repository @ WVU. For more information, please contact ian.harmon@mail.wvu.edu. 
Digitized by the Internet Archive in 2010 with funding from

Lyrasis Members and Sloan Foundation 
Bulletin 526T

\title{
Crisscross \\ Breeding \\ of Poultry
}

\author{
Ig-Eng. Elbrary
}

West Virginia University

Agricultural Experiment Station 


\section{THE AUTHORS}

Authors of Crisscross Breeding of Poultry are H. M. Hyre, Associate Poultry Geneticist. and M. R. McClung, Animal Scientist, and Chairman of the Department of Animal Industry and Veterinary Science.

SYMBOLS USED IN TABLES 2-6:

$\overline{\mathrm{x}}=$ Mean.

$\mathrm{s}=$ Standard diviation.

$\mathrm{s} \overline{\mathrm{x}}=$ Standard error of the mean.

$\mathrm{CV}=$ Coefficient of variation.

West Virginia UnNiversity

Agricultural Experiment Station

College of Agriculture and Forestry

A. H. Vanlandingham, Drregtor

MORGanTOWN 


\section{Crisscross Breeding of Poultry}

H. M. HYRE and M. R. McCLUNG

CRISSCROSS BREEDING of poultry consists of crossing two different breeds or strains to produce the $F_{1}$ progeny, and subsequent generations are produced by atternate use of males from the pure lines on the crossed pullets. Some prefer to call this rotational crossbreeding. Heterosis from this form of crossbreeding needed further study. The phenomenon of heterosis or hybrid vigor is well known from the crossing of breeds and varieties of both animals and plants. It is exhibited in poultry by improvement in hatchability, growth rate, and egg production. The extent to which this condition is obtained will depend upon the combining ability of the strains that are used for the various economic traits.

There are several methods of obtaining heterosis in poultry. Some of these are crossbreeding, strain crossing, the crossing of inbred lines, and crisscross breeding. Assuming that similar results could be obtained, crisscross breeding would appear to be the most economical method since only the males of the two pure lines would be used in the crisscross breeding program. The females used would be those produced by crisscross breeding. This type of a poultry breeding program could be used to advantage in several different plans. Commercial hatcherymen could enter into agreements with two different breeders to supply the males for the laying flocks that are to produce the hatching eggs. A fairly high degree of heterosis might be maintained by alternating the two different male strains from year to year. Small breeders with only one strain might increase heterosis in their stock by exchanging males. Crisscross breeding could be an excellent tool to be used in a franchised hatchery program. The poultry breeder would need to develop and maintain two different strains and supply the franchised hatcheries with males only.

Results from numerous crossbreeding experiments have been reported. Warren (1927) found hybrids to be definitely superior to either parental breeds in mean egg production. The $F_{1}$ progeny produced 23 per cent more eggs during the first year's lay than the White Leghorn which had the higher production of the two breeds used in the cross. Nordskog and Ghostley (1954) compared strain crosses, crossbreds, and pure strains. They found that in total eggs produced the three years' results farored strain crosses and crossbreds over the pure strains by 10 and 12 per cent, 
respectively. The Fi crosses also had a higher per cent hatchability, grew at a more rapid rate, and showed a lower mortality rate than either of the parental strains. Hyre et al. (1962) reported that $F_{1}$ females from various crosses produced at a higher rate than the parent stock with one exception. Cole and Hutt (1962) stated that continued selection and resultant improvement within pure strains can be obtained without loss of hybrid vigor when such strains are crossed and that such a method of obtaining better hybrids is practical. Skaller (1954) presented data which showed that heterosis in poultry may be produced by crisscross breeding as well as by crossbreeding as expressed in better hatchability, lower chick mortality, and higher egg production than the original pure strains. Nordskog and Phillips (1960) found a difference between reciprocal crosses in adult mortality among the breeds that they used.

\section{Experimental Procedure}

Four strains of chickens were used in this study. They consisted of two strains of White Leghorns, Leghorn 1 and Leghorn 2; one Rhode Island Red strain; and one New Hampshire strain. These strains were crossed to provide six different crosses as well as six different lines of crisscrosses. Individual pedigree records were kept on all pure lines and this information was used in the breeding program. Two hundred pullets in each of the pure lines were trapnested each year and approximately 75 hens were selected from each strain to be used as breeders for the next year. Six breeding pens were maintained for each of the four pure strains from which the individual pedigreed data were collected. Each of the six crossbred lines had 50 pullets and the crisscross lines had 30 pullets for each year from which the data were collected. The males used to produce the crosses and the crisscrosses were genetically similar to the males used in the pure lines. Individual records were not kept on the dams of the crosses and crisscrosses since the breeding system used with these lines was mass mating and the data were on a flock basis. Reciprocal crosses were not made in this study.

All chicks were hatched during the spring months and were brooded and reared together. The pullets were housed at approximately 5 months of age in similar laying quarters which provided $3 \mathrm{l} / 2$ square feet of floor space per bird. The same ration was fed to all groups and all environmental conditions were similar for all lines. Egg production records were kept for a period of 10 months. Data were collected on egg numbers, egg size, livability, fertility, and hatchability. 


\section{Results and Discussion}

The data presented here cover a period of three years and inclucle three groups of layers. These groups consisted of the purebred lines, the crossbred lines, and the crisscross lines. Mean performance of the breeding combination is given in Table 1. Egg production results shown here are given in per cent on a hen-dlay basis and cover the period from 28 to 65 weeks of age for all lines. These percentages are means resulting from three years of performance. The production of each of the purebreds used to make the crosses and crisscrosses is shown along with the results of the crosses and crisscrosses. These data show that in all but two instances, the crosses and crisscrosses out-performed the purebreds. The per cent mean production for the three groups-purebreds, crosses, and crisscrosses-may been seen in Table 2. Here it may be noted that the crossbred group has a mean per cent production of 64.7 , while that of the crisscross group is 65.2. There was no difference between these two groups in egg production; however, there was a higher significant difference between these two groups and that of the purebred group which had a mean production of 55.9 per cent. The analysis of variance for egg production is given in Table 7 .

Table 2 presents the phenotypic parameters for egg production, and it may be seen that the mean and variance in these data have moved together. The variation in production between the crossbred lines and the crisscross lines was very similar. Mean egg weights for the various lines are presented in Table 1. These weights were taken in February and March after the birds had been in production for 6 to 7 months. Egg weights for the light breeds were less than those for the heavy breeds. Table 7 gives the analysis of variance which shows that there is a higher significant difference between breed types.

Table 3 presents the mean egg weight in grams for the various groups. Egg weights for the purebreds, crosses, and crisscrosses were 58.9, 62.4 , and 61.8 grams per egg, respectively. This would seem to indicate that both types of crossing tend to increase egg size. Here, as in èg production, we find the mean and variance of these data have generally moved together.

Table 4 presents mean per cent livability for all lines. Livability was slightly improved in the crisscrosses over the crosses, $84.5 v s$. 83.7 , but the coefficient of variation was $12.5 \mathrm{vs}$. 7.3. This was due to wide variation between the combination in the crisscrosses in the ability to survive when averaged over years as well as wide fluctuations between years. The high- 


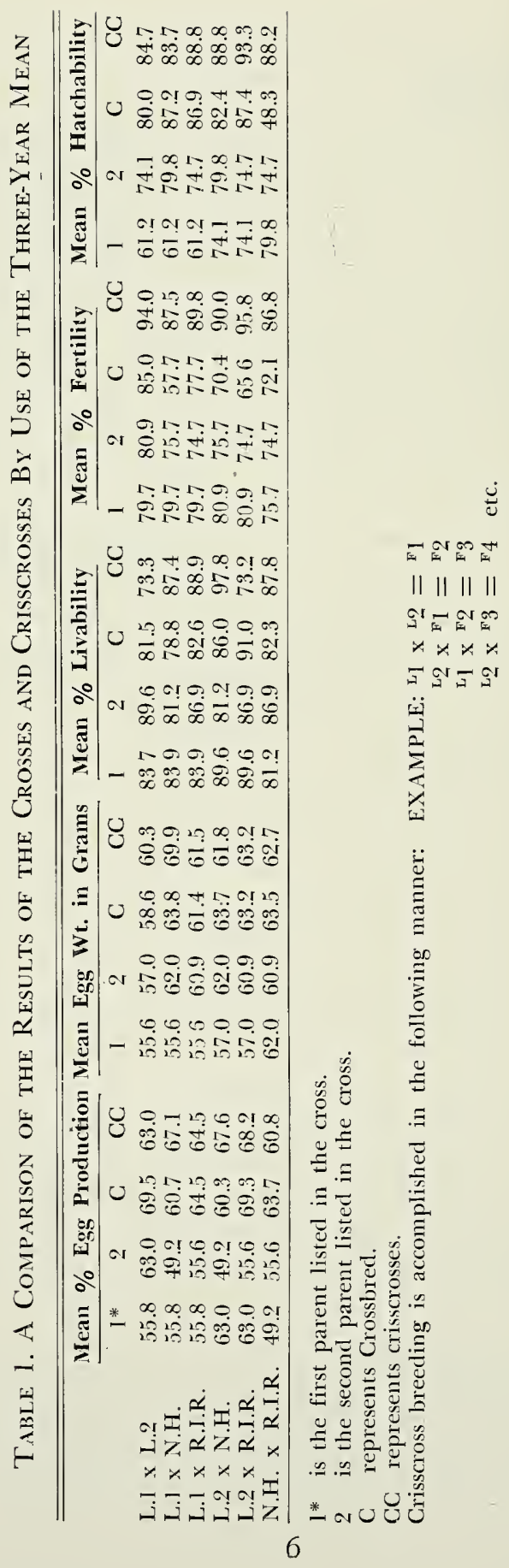


Table 2. General Statistical information Regarding the Three-Year Mean Per Cent Egg Production

\begin{tabular}{|c|c|c|c|c|}
\hline Purebred Lines & $\overline{\mathrm{x}}$ & $\mathrm{s}$ & $s \bar{x}$ & $\mathrm{CV}$ \\
\hline Leghorn $1 \ldots$ & 55.8 & 6.18 & 3.57 & 11.1 \\
\hline Leghorn $2 \ldots \ldots$ & 63.0 & $3.0 \mathrm{I}$ & 1.74 & 4.8 \\
\hline New Hampshires & 49.2 & 2.50 & 1.44 & 5.1 \\
\hline \multirow[t]{2}{*}{ Rhode Island Reds } & 55.6 & 4.79 & 2.76 & 8.6 \\
\hline & 55.9 & 4.12 & 2.38 & 7.4 \\
\hline \multicolumn{5}{|l|}{ Crossbred Lines } \\
\hline Leg. $1 \times$ Leg. 2 & 69.5 & 7.72 & 4.46 & I1.1 \\
\hline Leg. 1 x New Hampshires .. & 60.7 & 4.17 & $2.4 \mathrm{I}$ & 6.9 \\
\hline Leg. $1 \times$ Rhode Island Reds & 64.5 & 8.90 & 5.14 & 13.8 \\
\hline Leg. $2 \times$ New Hampshires ..... . . . . & 60.3 & 8.49 & 4.90 & I4.I \\
\hline I eg. $2 \times$ Rhode Island Reds ........... & 69.3 & 8.81 & 5.09 & 12.7 \\
\hline R. I. Reds $x$ New Hampshires .......... & 63.7 & 10.47 & 6.04 & 16.4 \\
\hline 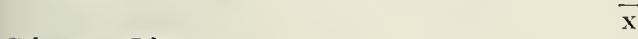 & 64.7 & 8.09 & 4.67 & 12.5 \\
\hline \multicolumn{5}{|l|}{ Crisscross Limes } \\
\hline$F_{1-2-3}($ Leg. $1 \times$ Leg. 2)* & 63.0 & 4.93 & 2.84 & 7.8 \\
\hline $\mathrm{F}_{1-2-3}$ (Leg. $\left.1 \times \mathrm{NH}\right)$.. & 67.1 & 9.21 & 5.32 & 13.7 \\
\hline$F_{1-2-3}$ (Leg. I x RIR) & 64.5 & 2.34 & 1.35 & 3.6 \\
\hline $\mathrm{F}_{1-2-3}($ Leg. $2 \times \mathrm{NH})$ & 67.6 & 11.03 & 6.37 & 16.3 \\
\hline$F_{1-2-3}(\mathrm{Leg} .2 \times$ RIR) $\ldots \ldots \ldots \ldots \ldots \ldots$ & 68.2 & 9.78 & 5.65 & 14.4 \\
\hline $\mathrm{F}_{1-3-3}(\mathrm{NH} \times \mathrm{RIR}) \ldots \ldots \ldots \ldots \ldots \ldots \ldots$ & 60.8 & 8.47 & 4.89 & 13.9 \\
\hline 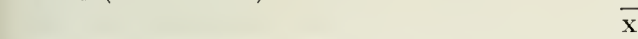 & 65.2 & 7.63 & 4.40 & 11.6 \\
\hline
\end{tabular}

${ }^{*} \mathrm{~F} I-2-3$ refers to the first, second and third generations. The breeds shown in the parenthesis are the two breeds involved in that particular cross. To produce the various generations the males of the two breeds are altemated. The females are the crossbreds from the previous generation.

Table 3. General Statistigal Information Regarding the Three-Year Mean of Egg Weight (Grams)

\begin{tabular}{|c|c|c|c|c|}
\hline Purebred Lines & $\overline{\mathrm{x}}$ & $\mathrm{s}$ & $\mathrm{sx}^{-}$ & $\mathrm{CV}$ \\
\hline Leghorn 1 .. & 55.6 & 1.04 & .60 & 1.9 \\
\hline Leghorn $2 \ldots \ldots$ & 57.0 & 1.20 & .69 & 2.1 \\
\hline New Hampshires .. & 62.0 & 1.83 & 1.05 & 2.9 \\
\hline \multirow[t]{2}{*}{ Rhode Island Redis } & 60.9 & 1.56 & .90 & 2.6 \\
\hline & 58.9 & 1.41 & .81 & 2.4 \\
\hline \multicolumn{5}{|l|}{ Crossbred Lines } \\
\hline Leg. $1 \times$ Leg. $2 \ldots$ & 58.6 & 1.90 & $\mathrm{I} .10$ & 3.2 \\
\hline Leg. 1 x New Hampshires ..... ... & 63.8 & 1.11 & .64 & 1.7 \\
\hline Leg. I $\times$ Rhode Island Reds $\ldots \ldots \ldots \ldots \ldots$ & 61.4 & 3.02 & 1.74 & 4.9 \\
\hline Leg. $2 \times$ New Hampshires . . . . . . . . . . . & 63.7 & 2.31 & 1.33 & 3.6 \\
\hline Leg. 2 x Rhode Island Reds. & 63.2 & 1.66 & .96 & 2.6 \\
\hline \multirow[t]{2}{*}{ R. I. Reds $\mathrm{x}$ New Hampshires } & 63.5 & 1.00 & .58 & 1.6 \\
\hline & 62.4 & 1.83 & 1.06 & 3.0 \\
\hline \multicolumn{5}{|l|}{ Crisscross Lines } \\
\hline $\mathbf{F}_{1-2-3}$ (Leg. 1 x Leg. 2) & 60.3 & 1.31 & .76 & 2.2 \\
\hline $\mathrm{F}_{1-2-3}$ (Leg. $\left.1 \times \mathrm{NH}\right)$ & 60.9 & 2.25 & 1.30 & 3.7 \\
\hline $\mathrm{F}_{1-2-3}$ (Leg. 1 x RIR) & 61.5 & 1.88 & 1.08 & 3.1 \\
\hline $\mathrm{F}_{1-2-3}($ Leg. $2 \times \mathrm{NH})$. & 61.8 & 2.84 & 1.64 & 4.6 \\
\hline$F_{1-2-3}$ (Leg. $2 \times$ RIR) & 63.2 & 2.97 & 1.71 & 4.7 \\
\hline \multirow[t]{2}{*}{$\mathrm{F}_{1-2-3}(\mathrm{NH} \times \mathrm{RIR}) \ldots$} & 62.7 & 2.51 & 1.45 & 4.0 \\
\hline & 61.8 & 2.29 & 1.32 & 3.7 \\
\hline
\end{tabular}


Table 4. General Statistical Information Regarding the Three-Year Mean of Per Cent Livability

\begin{tabular}{|c|c|c|c|c|}
\hline Purebred Lines & $\overline{\mathrm{x}}$ & $\mathbf{s}$ & $s \bar{x}$ & $\mathrm{CV}$ \\
\hline Leghorn 1 & 83.9 & 5.01 & 2.90 & 6.0 \\
\hline Leghorn $2 \ldots \ldots$ & 89.6 & 4.14 & 2.39 & 4.6 \\
\hline New Hampshires & 81.2 & 1.74 & 1.00 & 2.1 \\
\hline Rhode Island Reds & 86.9 & 6.72 & 3.88 & 7.7 \\
\hline Crelod & 85.4 & 4.40 & 2.54 & $5 . \mathrm{I}$ \\
\hline \multicolumn{5}{|l|}{ Crossbred Lines } \\
\hline Leg. I $x$ Leg. $2 \ldots \ldots$ & 81.5 & 5.64 & 3.26 & 6.9 \\
\hline Leg. I x New Hampshires. & 788 & 8.44 & 4.87 & 10.7 \\
\hline Leg. 1 x Rhode Island Keds & 82.5 & 11.93 & 6.89 & 14.5 \\
\hline Leg. $2 \times$ New Hampshires .. & 86.0 & 4.04 & 2.33 & 4.7 \\
\hline Leg. $2 \times$ Rhode Island Reds & 91.0 & 2.56 & 1.48 & 2.8 \\
\hline R. I. Reds x New Hampshires & 82.3 & 3.57 & 2.06 & 4.3 \\
\hline 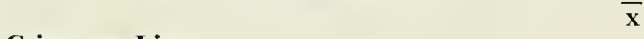 & 83.7 & 6.03 & 3.48 & 7.3 \\
\hline \multicolumn{5}{|l|}{ Crisscross Lines } \\
\hline$F_{1-2-3}($ Leg. $1 \times$ Leg. 2) & 72.3 & 7.07 & 4.08 & 9.8 \\
\hline$F_{1-2-3}($ Leg. $1 \times N H) \ldots$ & 87.4 & 4.54 & 2.62 & 52 \\
\hline$F_{1-2-3}$ (Leg. I x RIR) & 88.9 & 8.33 & 4.81 & 9.4 \\
\hline $\mathrm{F}_{1-2-3}($ Leg. $2 \times \mathrm{NH})$ & 97.8 & 3.85 & 2.22 & 3.9 \\
\hline $\mathrm{F}_{1-2-3}$ (Leg. $2 \times$ RIR) $\ldots \ldots \ldots \ldots \ldots \ldots$ & 73.2 & 23.62 & 13.64 & 32.3 \\
\hline $\mathrm{F}_{1-2-3}(\mathrm{NH} \times \mathrm{RIR}) \ldots \ldots \ldots \ldots \ldots \ldots \ldots \ldots$ & 87.8 & 12.62 & 7.29 & 14.4 \\
\hline$x_{0}$ & 84.5 & 10.01 & 5.78 & 12.5 \\
\hline
\end{tabular}

est and the lowest livability for breeding combination was found in the crisscrosses. The same line, Leghorn 2, was a member of both the best and the poorest living line. This would indicate the necessity of making use of this specific combining ability in fincling suitable lines for crossing. The analysis of variance showed there were no significant difference in livability between breed types (Table 7 ), but there was a difference between years.

Data on fertility and hatchability may be found in Table 1. It should be noted at the outset that the purebreds were in their second year of lay when the hatching eggs were produced, while the crosses and crisscrosses were in their first year of lay. Fertility for the crossbreds was extremely low in some combinations. This is believed to be at least partly clue to preferential mating. Fertility was a trait where the mean and variance did not move together (Table 5). Eggs were classed fertile or infertile by candling, and this difference here could be partly due to early embryonic death. This does indicate, however, a marked superior advantage for the crossbred female in fertility, hatchability (Table 6), and total chicks hatched. For every 100 eggs set 19 more live chicks were hatched when the dam was a crossbred compared to when she was a purebred within a cross. It might be concluded that the eggs produced by the crossbred clams furnished a better environment for both fertilization and embryo growth. These data would seem to suggest that a way should be found to have 
Table 5. General Statistical Information Regarding, the Three-Year Menn of Per Cent Fertility

\begin{tabular}{|c|c|c|c|c|}
\hline Purebred Lines & $\bar{x}$ & $\mathrm{~s}$ & $s \bar{x}$ & $\mathrm{CV}$ \\
\hline Leghorn 1 .. & 79.7 & 3.31 & 1.91 & 4.2 \\
\hline Leghorn $2 \ldots \ldots$ & 80.9 & 5.45 & 3.15 & 6.7 \\
\hline New Hampshires. & 75.7 & 6.85 & 3.95 & 9.1 \\
\hline \multirow[t]{2}{*}{ Rhode Island Reds } & $\therefore 74.7$ & 8.85 & 5.11 & 11.9 \\
\hline & $\overline{\mathrm{x}} 77.7$ & 6.12 & 3.53 & 8.0 \\
\hline \multicolumn{5}{|l|}{ Crossbred Lines } \\
\hline Leg. $1 \times$ Leg. $2 \ldots \ldots \ldots$ & . . 85.0 & .55 & .32 & .7 \\
\hline Leg. 1 x New Hampshires. & . 57.7 & 1763 & 10.18 & 30.6 \\
\hline Leg. 1 x Rhode Island Reds & . . 77.7 & 15.66 & 9.04 & 20.2 \\
\hline Leg. $2 \times$ New Hampshires .. & . . 70.4 & 14.79 & 8.54 & 21.0 \\
\hline Leg. $2 \times$ Rhode Island Reds. & . 65.6 & 4.10 & 2.36 & 6.3 \\
\hline \multirow[t]{2}{*}{ R. I. Reds $x$ New Hampshires } & . . 72.1 & 25.89 & 14.95 & 35.9 \\
\hline & $\overline{\mathrm{x}} 71.4$ & 13.10 & 7.56 & 19.1 \\
\hline \multicolumn{5}{|l|}{ Crisscross Lines } \\
\hline$F_{1-2-3}($ Leg. $1 \times$ Leg. 2) & . . 94.0 & 3.45 & 199 & 3.7 \\
\hline $\mathrm{F}_{1-2-3}($ Leg. $1 \times \mathrm{NH}) \ldots$ & . 87.5 & 5.97 & 3.45 & 68 \\
\hline$F_{1-2-3}$ (Leg. $1 \times$ RIR) & .. 898 & 5.40 & 312 & 6.0 \\
\hline $\mathrm{F}_{1-2-3}$ (Leg. $\left.2 \times \mathrm{NH}\right)$ & . . 90.0 & 7.14 & 4.12 & 7.9 \\
\hline $\mathrm{F}_{1-2-3}$ (Leg. $2 \times$ RIR & . 95.8 & 2.18 & 1.26 & 2.3 \\
\hline \multirow[t]{2}{*}{$\mathrm{F}_{1-2-3}(\mathrm{NH} \times \mathrm{RIR}) \ldots$} & . & 10.35 & 598 & 11.9 \\
\hline & $\bar{x} 90.7$ & 5.75 & 332 & 6.4 \\
\hline
\end{tabular}

Table 6. General Statistical Information Regarding the Three-Year Mean of Per Cent Hatchability

\begin{tabular}{|c|c|c|c|c|}
\hline Purebred Lines & $\bar{x}$ & $\mathrm{~s}$ & $s \overline{\mathrm{x}}$ & $\mathrm{CV}$ \\
\hline Leghorn 1 .. & 61.2 & 8.69 & 5.02 & 14.2 \\
\hline Leghorn $2 \ldots \ldots$ & 74.1 & 6.52 & 3.77 & 8.8 \\
\hline New Hampshires ... & 79.8 & 2.74 & 1.58 & 3.4 \\
\hline \multirow[t]{2}{*}{ Rhode Island Reds } & 74.7 & 2.77 & 1.60 & 3.7 \\
\hline & 72.5 & 5.18 & 2.99 & 7.5 \\
\hline \multicolumn{5}{|l|}{ Crossbred Lines } \\
\hline Leg. $1 \times$ Leg. $2 \quad \ldots \ldots \ldots$ & 80.0 & 8.99 & 5.19 & 112 \\
\hline Leg. $1 \times$ New Hampshires. & 87.2 & 5.46 & 3.15 & 6.3 \\
\hline Leg. $1 \times$ Rhode Islaud Reds ... & 86.9 & 4.34 & 2.50 & 50 \\
\hline Leg. $2 \times$ New Hampshires $\ldots \ldots \ldots \ldots \ldots$ & 82.4 & 8.87 & 5.12 & 108 \\
\hline Leg. $2 \times$ Rhode Island Reds $\ldots \ldots \ldots \ldots$ & 87.4 & 4.00 & 2.31 & 4.6 \\
\hline \multirow{2}{*}{ R. I. Reds $x$ New Hampshires ... } & 84.3 & 5.78 & 3.34 & 6.9 \\
\hline & 84.7 & 6.24 & 3.60 & 7.4 \\
\hline \multicolumn{5}{|l|}{ Crisscross Lines } \\
\hline$F_{1-2-3}($ Leg. $1 \times 2)$ & 84.7 & 8.22 & 4.75 & 9.7 \\
\hline $\mathrm{F}_{1-2-3}(\operatorname{Leg} .1 \times \mathrm{NH})$ & 83.7 & 11.05 & 6.38 & 13.2 \\
\hline$F_{1-1-3}$ (Leg. I x RIR) & 88.8 & 4.99 & 2.88 & 5.6 \\
\hline $\mathrm{F}_{1-3-3}$ (Leg. $\left.2 \times \mathrm{NH}\right)$ & 88.8 & 4.78 & 2.76 & 5.4 \\
\hline$F_{1-2-3}$ (Leg. $2 \times$ RIR) $\ldots$ & 93.3 & 3.59 & 2.07 & 3.9 \\
\hline \multirow[t]{2}{*}{$\mathrm{F}_{1-1-3}(\mathrm{NH} \times \mathrm{RIR}) \ldots \ldots$} & 89.6 & 7.12 & 4.11 & 8.0 \\
\hline & 88.2 & 6.62 & 5.82 & 7.6 \\
\hline
\end{tabular}

crossbred females at all levels possible in the poultry industry. A franchised breeder controlling his own breeding stock would be at a serious disadvantage if he did not make use of this phenomenon. 
Table 7. Analysis of Variance for Egg Production Livability and Egg Size of Years and Breed Type

\begin{tabular}{|c|c|c|c|c|c|c|c|}
\hline \multirow{2}{*}{$\begin{array}{l}\text { Source of } \\
\text { Variation }\end{array}$} & \multirow[b]{2}{*}{ df } & \multicolumn{2}{|c|}{ Egg Production } & \multicolumn{2}{|c|}{ Livability } & \multicolumn{2}{|c|}{ Egg Size } \\
\hline & & M.S. & $\mathbf{F}$ & M.S. & $\mathbf{F}$ & M.S. & $\mathbf{F}$ \\
\hline Total & 47 & 71.02 & & 68.68 & & 8.49 & \\
\hline Years & 2 & 695.54 & $27.63^{* *}$ & 266.86 & $4.08^{*}$ & 1.79 & .25 \\
\hline Breed type & 2 & 445.23 & $17.96^{* *}$ & 30.72 & .47 & 47.35 & $6.62 * *$ \\
\hline Years $\mathrm{x}$ & & & & & & & \\
\hline breed type & 4 & 18.61 & 0.74 & 20.09 & .31 & 5.24 & .73 \\
\hline $\begin{array}{l}\text { Within } \\
\text { sub class }\end{array}$ & 39 & 25.17 & & 65.44 & & 7.15 & \\
\hline
\end{tabular}

Analysis of variance was computed for per cent egg production, livability, and egg size. Means were used in the analysis for years, breed types, and years $\mathrm{x}$ breed types. Livability was analyzed by converting per cent livability to angles before analyzing.

Table 7 shows the analysis of variance for the traits mentioned. It may be noted that there was a highly significant difference in mean per cent production between breed types and a highly significant difference in egg size between breed types.

\section{Summary and Conclusions}

The performance of purebred, crossbred, and crisscross chickens was investigated. Two strains of White Leghorns, one strain of New Hampshires, and one strain of Rhode Island Reds were used. Six lines of crosses and six lines of crisscrosses were made from these four strains of purebreds. Data were collected and the results for three generations of the 16 lines were compared. The results are also summarized by the three principal groups of layers; purebreds, the crosses, and the crisscrosses. There were no differences in the mean per cent production for the three generations of the crosses and the crisscrosses. The mean per cent production of the purebrecls was significantly less than that of the other two groups.

Livability was found to be similar for all three groups.

Egg weight for the two heavy breeds was greater than that of the Leghorns. The mean egg size of the crosses and crisscrosses was greater than that of the purebreds. This would indicate that both types of crosses tend to increase egg size.

Results from this study show a much greater mean per cent fertility for the crisscross group than for the other two groups. The mean per cent hatchability was also found to be greatest for the crisscross group, although it was only 4 per cent more than for the crossbreds. 
The crisscross pullets exhibited as much, and in some instances more, heterosis than the crossbred pullets in such economic traits as egg production, egg weight, fertility, and hatchability. Crisscross breeding coulcl be expected to give results similar to crossbreeding, but should be more economical than crossbreeding since the crisscross pullets would be used to produce the hatching eggs. In the crisscross program the females are crossbreds and tencl to produce a greater number of live chicks from the total eggs set.

\section{References}

Cole, R. K. and F. B. Hutt. 1962. The effect of continued selection in pure strains upon their combinability. Poultry Sci. 41: 1636.

Hyre, H. M., C. J. Cunningham, R. S. Dunbar, Jr. and T. B. Clark. 1962. Breeding for efficient production of eggs and poultry meat. W. Va. Univ. Agr. Expt. Sta. Bul. 479.

Nordskog. A. W. and F. L. Ghostly. 1954. Strain crossing and crossbreeding compar ed with closed flock bleeding. Poultry Sci. 33: 704-715.

Nordskog, A. W. and R. E. Phillips. 1960. Reciprocal crosses involving Leghorns, heavy breeds and Fayoumi. Poultry Sci. 39: 257-263.

Skaller, F. 1954. Heterosis from crisscross breeding in poultry. Proc. 10th Worlıl's Poultry Congress. p. 59.

Warren, D. C. 1927. Hybrid vigor in poultry. Poultry Sci. 7: 1-8. 
Hilling

angong

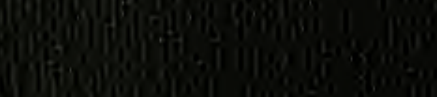

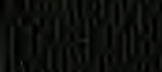

alom

影诸

along

thing:

owas

A.

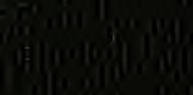

